\title{
En ausencia de virreyes: la naturaleza política del alter ego durante el gobierno interino de la Real Audiencia de Lima (1672-1674)
}

\section{In the absence of viceroys: the political nature of the alter ego under the interim government of the Royal Audience of Lima (1672-1674)}

JUAN JIMÉNEZ CASTILLO

Universidad Autónoma de Madrid (UAM)

juan.jimenezc@uam.es

\section{RESUMEN}

La muerte del virrey conde de Lemos en 1672 dejó al reino del Perú sin su cabeza política durante un año y medio, quedando al mando la Real Audiencia de Lima en interinidad, lo que produjo numerosos desajustes hasta la llegada al solio virreinal de don Baltasar de la Cueva, conde de Castellar. En este contexto, se analizan las controversias gubernativas ocasionadas por la ausencia del oficio de virrey, al mismo tiempo que se concreta la naturaleza politica virreinal a partir de los gobiernos interinos, en un momento en el que la Monarquía Católica atravesaba por un proceso de reconfiguración que afectó a la composición de los reinos y a la transfiguración de los oficios. La hipótesis de este trabajo propone que los virreyes ejercieron como centros de orden y vertebración politica, y sus ausencias concretadas en audiencias en interin manifestaron mayores incertidumbres y vacios de poder en el control efectivo del reino peruano debido a su multiplicidad.

Palabras clave: Audiencia, gobierno interino, conde de Lemos, conde Castellar, reino del Perú 


\section{ABSTRACT}

The death of Viceroy Conde de Lemos, and the subsequent interim rule of the Royal Audience of Lima, caused significant disruption in the Viceroyalty of Peru until the arrival of the new Viceroy, don Baltasar de la Cueva, Conde de Castellar. This article examines the governance issues raised by the Viceroy's absence; and studies the evolving nature of viceroyal politics, as reflected by developments during the interim period. Crucially, the latter occurred at a time of change in the Spanish Monarchy, with implications for the composition and governance of viceroyal domains. The working hypothesis is that the figure of the viceroy played an important role in preserving order and concentrating political authority; and that the latter diluted during interim governments, resulting in uncertainty and a considerable power vacuum.

Keywords: Audiencia, interim government, count of Lemos, count of Castellar, Kingdom of Peru

$\mathrm{D}$ esde el descubrimiento y conquista del Nuevo Mundo, las sucesivas audiencias gobernadoras novohispanas se caracterizaron por la insuficiencia de control y unificación de dichas provincias, materializadas en tumultos y rebeliones por los conquistadores que amenazaban a la Corona la pérdida de las Indias. ${ }^{1}$ Con la erección de los virreinatos de México en 1535 y Perú en 1542, se soslayó la falta de una jurisdicción territorial definida y, por lo tanto, del establecimiento de una férrea autoridad. ${ }^{2}$ La unicidad que encarnaba el que hacía las veces de rey se hizo cada vez más apremiante, ya que en sus ausencias se propiciaba un retraso en la toma de decisiones ejercidas por la Audiencia, lo que provocaba momentos de inquietud, como los ocurridos entre 1672 y 1674 tras la muerte del virrey del Perú, Pedro Fernández de Castro, conde Lemos. Las dificultades administrativas vinieron determinadas por la inestabilidad

1 Salinero indica que durante la primera mitad del siglo XVI «la Corona no había conquistado las Indias» (2017: 15); Merluzzi 2006: 87-106.

2 Semboloni 2014: 65-76 y 143-178; Torres 2014: 69-111. 
política y la conflictividad e imprecisión de facultades sobre el gobierno civil en manos de la Audiencia provocada a raíz de esta vacante. ${ }^{3}$

La importancia acaparada por la figura virreinal, así como la inconsistencia política manifestada por dichos tribunales — a pesar de ejercer como órganos superiores de justicia y desplegar un poder relativo en diferentes regiones indianas - han sido los dos factores que han provocado un vacío historiográfico en el estudio de las audiencias interinas. ${ }^{4} \mathrm{~A}$ lo largo de la historia virreinal, no fueron pocas las vacantes ocupadas por estos tribunales. Entre el siglo XVI y XVII, en el reino del Perú hubo un total de seis gobiernos interinos presididos por la Real Audiencia de Lima, con la dificultad que acarreaba gobernar con suficiente autoridad frente a los demás juzgados americanos. El tribunal limeño se erigió como la principal rectora en ausencia de virreyes, debido a que su «antigüedad, autoridad y número de ministros excede a las demás».5

Para el jurista Juan de Matienzo, la audiencia era el cuerpo permanente que "aseguró la tierra» y enraizó la vida cívica en los reinos americanos, en la que sus jueces fundaron importantes «dinastías criollas», jugando un papel relevante en el desarrollo de la vida política y social hispanoamericana. ${ }^{6}$ El tribunal de la ciudad de Los Reyes se caracterizó por actuar como primera audiencia — presidencial — y ejercer el control de manera privativa sobre los tribunales subordinados de Quito y Charcas, cuyos presidentes no mantuvieron el oficio de gobernador. Tenía competencia

${ }^{3}$ Aunque estos gobiernos se sucedieron de forma irregular, desde la erección del virreinato peruano (1542) hasta el último (1824) se produjeron diecinueve años de mandatos interinos, abarcando más de dieciocho años sin virrey. El caso más llamativo fue el del siglo XVI con unos ocho mandatos interinos desde la conformación del virreinato — con un gobierno de facto presidido por Gonzalo Pizarro-, que en total sumaron doce años aproximadamente. Para el siglo XVII, sumaron seis años y cinco meses contando con el del arzobispo Liñán y Cisneros. Durante los primeros quince años del siglo XVIII, hubo cuatro gobiernos interinos sumando dos años y diez meses. En el siglo XIX, se produjo un solo gobierno de un período de siete meses y medio aproximadamente.

${ }^{4}$ Puente Brunke 2019: 83-97; Vargas Ugarte 1971, III: 334. Este último apenas hace referencia al análisis de las vacantes realizadas por la Real Audiencia de Lima durante el siglo XVII. Véase Tovar Velarde 1957-1958: 338-453.

${ }^{5}$ Solórzano Pereira 1648: 770-771.

${ }^{6}$ Fernández Sotelo 2007: 21-68. 
exclusiva para administrar justicia, asesorar a los virreyes a través del Real Acuerdo, Junta de Guerra, Hacienda y ejercer de asesora a la Corona, además de asignar delegados fiscales para visitas e inspecciones hacendísticas. ${ }^{7}$ Igualmente, pretendieron en más de una ocasión administrar de forma exclusiva sus demarcaciones, llegando a repartir encomiendas y mercedes, dado que en vacante de virreyes, la Audiencia, y con ella el oidor decano, asumía el mando con suprema autoridad. ${ }^{8}$ El problema del gobierno en ínterin fue que entrecruzaba las competencias del tribunal de justicia con aquellas que mantenían los virreyes, superponiéndose unas y otras, así como la insuficiencia para resolver a tiempo diferentes instancias de gobierno que requerían inmediatez.

Todo ello se dio en torno al período que gobernó la Audiencia entre 1672 y 1674 . Esta aprovechó la situación para desestabilizar ciertas facultades virreinales y acaparar ciertas competencias reservadas al alter nos. ${ }^{9}$ La crítica de muchos virreyes sobre estos gobiernos vino determinada a que no se respetaba el orden jerárquico presidido por el alter ego como unicidad de gobierno, y como ente al que únicamente le compete la soberanía política, pudiendo realizar consultas voluntarias con la Real Audiencia. ${ }^{10}$ Fue esto lo que intentó restablecer Baltasar de la Cueva y Enríquez, virrey conde de Castellar, a su llegada al Perú, siendo uno de los últimos virreyes indianos con mayor decoro y autoridad. ${ }^{11}$ Don Baltasar realizó una defensa de sus intereses y prerrogativas, tal y como le había

7 Lohmann Villena 1974: xi-xiv; Konetzke 1953-1962, II: 124-126; 257-258; 284-285 y 301-305.

8 Matienzo 1910: 121-137.

9 El alter nos o alter ego -«otro yo»- es el apelativo en latín empleado para denominar al virrey, como el lugarteniente y desdoblamiento del monarca al que representa de forma inmediata y como príncipe en el reino. El licenciado Matías de Caravantes, a principios del siglo XVII, definió al virrey como la "persona que desnudándose de la suya, viste la del Rey» y que «no es distinto de la persona real, pues en él vive por translación y copia con tal unión e ygualdad que la mesma honrra y reverencia que se deve a su Magestad se debe a su Excelencia" (Arregui 1985: 3-95). De manera similar lo indica Rafael de Vilosa en su Disertación Jurídica y Política, describiéndolo como cabeza de cuerpo místico político que abandera en nombre del soberano (1670: 103-128).

10 Fuentes 1859.

11 Suárez Espinosa 2017: 69-96. 
otorgado la reina doña Mariana de Austria hasta la llegada de don Juan José de Austria, ${ }^{12}$ lo que derivó en un cambio de paradigma político del sistema virreinal, materializado en la caída en desgracia de Castellar. Las reformas políticas realizadas correspondían con la nueva justificación política de la Monarquía Católica, basadas en un mayor centralismo concentrado en el Consejo y Cámara de Indias y tribunales de justicia. Todo ello manifestaba síntomas de una rearticulación de los espacios jurisdiccionales, que afectó de manera directa al nuevo papel que debían de adquirir los oficiales al servicio de la monarquía. ${ }^{13}$

El presente estudio analiza dichas inconsistencias políticas tras la muerte del virrey conde de Lemos, adquiriendo el poder en ínterin la Real Audiencia entre 1672 y 1674, a raíz de la falta de virrey como eje de autoridad, así como de oficiales que congregaban la unidad — presidentes de audiencias o capitanes generales- Conforme a estos acontecimientos, se examinarán las repercusiones gubernativas que en el virreinato peruano provocaba la ausencia del alter nos, las dificultades administrativas, así como la naturaleza política de los virreyes con pretensiones absolutas, que manifiesta la potestad profesada por el alter ego como padre de familia, sin excluir las problemáticas que mantuvo Castellar durante su gobierno, propias de la lucha de intereses entre facciones.

Tras la llegada al Perú de don Baltasar de la Cueva en 1674, se produjeron ciertas reformas que pretendían consolidar el poder de los virreyes como jerarquía irrefutable, evitando que las vacantes interinas cayeran en manos de las audiencias, afianzando el gobierno unipersonal — fundamentado en la unidad - frente al asambleario — multiplicidad—, un debate sobre teoría política que se remontaba a los autores clásicos. ${ }^{14} \mathrm{La}$ consecución de esta estrategia significaba efectuar una reforma que la Corona había intentado aplicar sin éxito desde la instauración virreinal en América, con el fin de que los virreyes no se convirtieran en príncipes absolutos en los reinos. Estas reformas iniciadas durante las dos últimas décadas del reinado de Carlos II, las heredaron los gobernantes

12 Mitchell 2019: 1-8.

13 Rivero Rodríguez 2019: 48-49.

14 Aristóteles 2014a; Plotino 1985; Aquino 1959; Maquiavelo 2018, I: 67-71. 
borbónicos, lo cual permitió una continuidad gubernativa de virreyes en el Perú desde la finalización de la Guerra de Sucesión española en 1715, último mandato en ínterin de la Audiencia durante el siglo XVIII. Ahora bien, para comprender en su complejidad la realidad política orquestada entre 1672 y 1674 , es necesario describir brevemente la composición política virreinal en las Indias.

\section{LA ESENCIA DE LA PRESENCIA: UN ANÁLISIS DEL SISTEMA DEL PODER VIRREINAL}

La articulación política de los territorios americanos incorporados a la Corona de Castilla se estructuró a semejanza del sistema cortesano virreinal heredado — aunque con divergencias - del que empleó la Corona de Aragón en los reinos mediterráneos. ${ }^{15}$ El despliegue de una "política de la presencia» adquirió tintes teológicos, ${ }^{16}$ al desdoblar la figura regia en un alter ego que le permitió gobernar en la distancia como "Cabeça del Cuerpo Místico que con el forman los Ministros". ${ }^{17} \mathrm{La}$ necesidad de establecer la viva imagen del rey como primera autoridad en el Nuevo Mundo se manifestó desde la incorporación de América a la Monarquía, ya que la administración derivada de las primeras audiencias en Nueva España, así como la falta de un príncipe soberano en los territorios andinos, originaron serias dificultades de gobierno traducidas en tumultos y revueltas. ${ }^{18}$

Ni gobernadores ni tribunales de justicia llegaron a representar una independencia administrativa frente a la autoridad de conquistadores, descubridores y primeros encomenderos. A causa de este desafío, se llevó a cabo una articulación de los reinos americanos que evitara la amenaza de caos y desorden, que tuvo como resultado la incorporación del sistema virreinal. El virrey operó como vértice regio, ya que «estas

\footnotetext{
${ }^{15}$ Lalinde Abadía 1967: 5-244.

16 Juan de Palafox argumentó que los santos eran «imágenes vivas de Dios» (Cañeque 2014: 192).

17 Vilosa 1670: 111; Kantorowicz 2012. El reino de Portugal también implantó en sus territorios este «estado do príncipes» que reconocían al virrey-gobernador como superior en el reino vicerealeza, pero con jurisdicción delegada (Oliveira 1991: 9-45).

18 Martiré 2005: 92-98.
} 
cosas de govierno se exercen mejor por uno, que por muchos». ${ }^{19} \mathrm{El}$ arquitecto de este sistema fue el Canciller de Indias, Mercurio Arborio di Gattinara, quien proveyó un régimen político sólido para una Monarchia Universalis. ${ }^{20}$

El virrey como representante vivo del monarca se tornó consustancial a la configuración de los reinos, ya que el sistema monárquico se asemejaba al gobierno de una casa; y el poder regio, al que ejerce un padre sobre sus hijos. ${ }^{21}$ Para ello, se eligió a miembros de la alta nobleza vinculados al gobierno regio y copartícipes en las funciones y servicios de la monarquía, desdoblando la figura mayestática del príncipe en los reinos. El virrey (nobleza) como ser que emanaba del monarca (realeza) tuvo que ser hipostasiado de todos los atributos (quididad) necesarios para el gobierno en las Indias, lo que consumó su autoridad y dignidad política regia bajo una potestad delegada, y que incluía un boato que lo volvía rey en el reino, como expresó el virrey novohispano don Martín Enríquez de Almansa. ${ }^{22} \mathrm{La}$ "nobleza» como prolongación de la realeza y la «unidad» como materialización del orden, graduación e instauración de autoridad, permitieron emitir un fiel reflejo y esceneficar un simulacro mayestático en los reinos de ultramar, ${ }^{23}$ facultándoles para gobernar jerárquicamente, lo que no ocurrió cuando las audiencias mantuvieron el poder. El virrey emergió como necesidad y resultado de un cálculo derivado del monarca que lo engendró por translación y copia de su esencia, como a "persona que, desnudándose de la suya, viste la del Rey, con la mesma potestad aunque limitada en parte por tener su Magestad en señal de supremo señorío reservadas a su corona algunas baptiçadas con nombre de regalías». ${ }^{24}$

Para suplir la ausencia política y simbólica del monarca en territorios tan distantes, se asimiló la forma cimentada en la Casa Real y el sistema

\footnotetext{
19 Solórzano Pereira 1648: 771.

${ }^{20}$ Boone 2014: 37-44.

${ }^{21}$ Aristóteles 2015: 86.

${ }^{22}$ Ms.3207, BNE, f. 680.

23 Alighieri 2009: 13-16.

${ }^{24}$ Arregui Zamorano 1985: 8-9.
} 
cortesano como elementos de organización política, según la cual se sustentaron todas las monarquías europeas desde la baja Edad Media. ${ }^{25}$ El simulacro real se completó al erigir todas las condiciones propias de una Corte Real tanto en Lima como en México, tras levantar un palacio real donde habitaría el virrey y su séquito, instaurando así un protocolo y servicio doméstico que reflejaba la composición del reino. ${ }^{26}$ Los virreinatos se desplegaron como «espacios de irradiación» y se desarrollaron bajo complejas redes de patronazgo (fidelitas), las cuales permitieron reinar en la distancia. Esta dotación simbólica a las cortes virreinales imprimió un lenguaje de poder directo y conciliador (symballein) que facultó y jerarquizó el conjunto de los reinos como centros de poder y prolongación de la Casa del Rey. ${ }^{27}$ Por último, el protocolo o etiqueta cortesana vertebró el cosmos sociopolítico bajo un decoro que esparció graduación y potestad, ${ }^{28}$ e hizo posible la epifanía regia y manifestar su autoridad suprema. ${ }^{29}$

El virrey completó de manera efectiva la presencia regia al ser hipostasiado con la mayor de las regalías, esto es, la concesión de mercedes y oficios entre los súbditos, que le permitió premiar a través de la liberalidad (justicia distributiva), lo cual lo convirtió en espejo del soberano (dignidad principesca), ${ }^{30}$ al conformar redes de patronazgo, y superponiéndose a regidores, alcaldes del crimen, corregidores u oidores. ${ }^{31}$ El vicesoberano

25 Adamson 2000: 7-41.

${ }^{26}$ Cañeque 2004a: 26-35; 51-78; Osorio 2008: 57-102.

${ }^{27}$ Bodino 1590: 6-11.

${ }_{28}$ Advertencias de las cosas en que ha de tener particular cuidado el Virrey de la Nueva España, Anónimo, 1603?, BNE, Ms.3207: 680; Relación de los estilos y tratamientos que los virreyes del Perú usan con los tribunales, ministros, prelados, cabildos, eclesiásticos, seculares y otras personas, la cual remitió el Marqués de Guadalcázar al Conde de Chinchón, 1628, BNE, Ms.3079: 27r-38v. Según el Diccionario de Autoridades (Real Academia Española 1726-1739), etiqueta es «el ceremonial de los estilos, usos y costumbres que se deben observar y guardar en las Casas Reales, donde habitan los reyes». Véase además, Elias 2012: 108-152. Las etiquetas quedaron reguladas en Leyes de Indias 1774: 63r-75r.

${ }^{29}$ Carrió-Invernizzi 2008: 15-30.

${ }^{30}$ Plotino 1985: 68. Cortiada argumentaba que el Alter Nos «representa la real persona de S.M. y es otro rey representado» (1676: 15).

31 Cañeque 2005: 7-42. 
mantuvo el elemento de la unicidad que le confería autoridad regia diferenciándolo del resto. La congregación del poder de manera unitaria habilitó al monarca a manifestarse en el virrey al causar una "continuidad sin fisuras», $y$, de este modo, expandirse espacialmente y alcanzar la forma de un reino-señorío. A través del alter ego, el monarca se perpetuaba a sí mismo en otro permaneciendo intacto, adquiriendo una plena ubicuidad al repetirse en su «otro yo» y alcanzar un espíritu doméstico como padre de familia. El alter nos como rey representado se desplegó como receptáculo e «imagen $»^{32}$ de quien lo engendró y nutrió de afecciones, encarnando la unicidad y, como tal, el orden de donde emanaba toda fuente de poder.

No obstante, la representatividad regia de la audiencia congregada por todos los oidores reconoció la proyección simbólica y manifiesta del monarca bajo un marcado carácter místico y figurativo — no natural como en el virrey-, que custodiaba el cumplimiento de la ley, ${ }^{33} \sin$ evidenciar la unicidad y supremacía de gobierno. A causa de ello y de la diversidad de pareceres, estos tribunales ocasionaron diversas fracturas gubernativas, como se observó en la distribución de competencias y ejecución administrativa, las cuales fueron las afrentas más relevantes a la que tuvo que oponerse cada virrey tras un gobierno interino. ${ }^{34}$ Esto en modo alguno confirma la presencia de una lucha de frenos y contrapesos o de negociación entre las diferentes repúblicas de poder (balance and power)..$^{35}$ Los conflictos entre arzobispos frente a vicereyes «formaba parte de la propia naturaleza del sistema político", dado que las demarcaciones religiosas y políticas no estaban plenamente definidas. ${ }^{36}$ La ausencia de virreyes propició continuas luchas jurisdiccionales entre ambos grupos de poder con el fin de acaparar mayores potestades.

32 Leyes de Indias 1774: f. 12r; Aquino 1959, III: 568.

33 Tau Anzoátegui 2016: 1-29.

${ }^{34}$ Fuentes 1859, II: 108-112.

35 Suárez Espinosa 2015: 215-228.

${ }^{36}$ Cañeque 2018: 17-25; Matienzo 1910: 117-120. Los virreyes solo podían gobernar, pero no castigar, que era competencia de las audiencias. 


\section{LAS INCONSISTENCIAS DE LOS GOBIERNOS INTERINOS POR AUDIENCIAS}

Durante el reinado de Carlos II (1665-1700), el Perú sufrió una interrupción continua en el relevo del solio virreinal. Desde la muerte del virrey don Diego de Benavides y de la Cueva, conde de Santisteban, en 1666, hasta el fallecimiento de don Melchor Portocarrero Lasso de la Vega, conde de la Monclova, en 1705, hubo un total de cinco gobiernos presididos por virreyes y otros tres interinos. El reemplazo entre el duque de la Palata y el conde de la Monclova en 1689 fue el único momento que no hubo vacante en manos de la Audiencia. De todos estos mandatos transitorios, dos de ellos fueron presididos por el tribunal limeño y uno por el arzobispo de Lima don Melchor de Liñán y Cisneros. Ambos sumaron algo más de seis años de interinidad en un total de más de cuarenta años de gobierno virreinal, lo que supuso una mayor dificultad para administrar el reino, dado los intervalos en los que se produjeron dichas vacantes interinas. ${ }^{37}$

La falta de unicidad en las decisiones por los gobiernos presididos por audiencias se caracterizó, entre otras, porque asumieron el mando interino sin que se les precisaran de instrucciones especiales, dado que eran regencias producidas por causa de fuerza mayor, y «porque claramente no tenían el poder o la responsabilidad suficiente en virtud de que pronto serían reemplazadas». ${ }^{38}$ Ello se observa en las breves relaciones o memorias que las audiencias tramitaron a los virreyes sucesores a lo largo de los siglos XVI y XVII. El caso abordado en este artículo fue el que realizó el tribunal limeño tras la muerte del conde de Lemos, fechada el 1 de agosto de 1674. La relación de gobierno que la Audiencia de

${ }^{37}$ Entre abril de 1666 y el 21 de noviembre de 1667, se sucedió la interinidad bajo la presidencia de Bernardo de Iturrizarra; el segundo gobierno interino por don Álvaro de Ibarra como oidor decano, entre el 14 de diciembre de 1672 y el 15 de agosto de 1674; la tercera a manos del arzobispo de Lima don Melchor de Liñán y Cisneros, entre el 7 de julio de 1678 y el 7 de noviembre de 1681 .

${ }^{38}$ Hanke 1980, V: 9. No obstante, en modo alguno supusieron una fragilidad de gobierno, dado que fueron los rectores de la organización territorial quienes atendían a los intereses locales, con los que los oidores mantenían profundos lazos con corregidores, encomenderos entre otros. Al respecto, véase Puente Brunke 2006 y 2016: 133-148 y 2012: 49-68. 
Lima ofreció al conde de Castellar apenas introduce datos relevantes y detallados, narrado de manera casi anecdótica, sin la precisión y certeza que dejaban las relaciones de los virreyes, ya fueran por silenciar iniciativas a futuros sucesores y, con ello, debilitar el poder regio del alter ego y acrecentar sus intereses. ${ }^{39}$ Igualmente, la comunicación con el Consejo de Indias era muy escasa, lo cual indicaba la falta de mediación política entre el reino y la Corona que representaba estos gobiernos.

Así se contempla en el anuncio del fallecimiento del virrey conde de Lemos, que fue tramitado al Consejo por el presidente de la Audiencia de Panamá, don Antonio Fernández de Córdoba, por pliego del gobernador de Cartagena, sin que llegara carta oficial de la audiencia limeńa a Madrid. El Consejo de Indias tuvo que dar por fidedigna la carta remitida por el presidente panameño al tratarse de un ministro leal a la Corona, el cual habría tenido noticia directa de Lima. Desde el 6 de diciembre de 1672, muerte del virrey conde de Lemos, hasta el 15 de agosto de 1674, entrada del virrey conde de Castellar, el virreinato se encontró «sin cabeza», con los "gravísimo inconveniente» que ello ocasionaba. Así lo anunció el presidente de Panamá, ya que «no ay otra forma más conveniente en el contingente de faltar virrey» que nombrar a uno de manera inmediata. ${ }^{40} \mathrm{La}$ audiencia limeña en carta de 7 de diciembre de 1672, justo un día después del fallecimiento de Lemos, avisó, como tenía obligado, de la ventaja de nombrar a un sucesor para que rigiese aquellas provincias, aunque esta advertencia no llegó directamente al Consejo. El oidor decano don Álvaro de Ibarra, presidente de la Audiencia de Lima y presentado para el obispado de Trujillo, fue quien tramitó dicha cuestión a Madrid, consciente de la gravedad del asunto, para que «sin dilación vaya Virrey; y no se dé tiempo a que gobiernen los Oidores». ${ }^{41}$ Antes de su deceso, el conde de Lemos vaticinó los problemas que ocasionarían la muerte o ausencia del alter ego, pues notificó en varias ocasiones al Consejo de Indias la necesidad de que hubiese un virrey en ínterin previamente escogido, optando por los más adecuados y

${ }^{39}$ Gobiernos de la Audiencia de Lima, BNE, Ms.3122: 62r-86v.

${ }^{40}$ Archivo General de Indias [en adelante AGI], Lima, 11.

${ }^{41}$ AGI, Indiferente, 1513. 
meritorios. Entre ellos, apostaba por el arzobispo de Lima o los presidentes de las audiencias de Charcas o Quito, así como alguno de los obispos del reino. Agregó que sería más conveniente elegir al arzobispo por su cualidad y talento debido al conocimiento y manejo que mantenía sobre la ciudad y provincia de Lima, sin olvidar la unicidad que representaba como máxima autoridad eclesiástica, lo que reunía la representación mística y natural del monarca en su figura. ${ }^{42}$ Meses antes de su desaparición, el conde de Lemos volvió a tramitar en carta de 3 de junio de 1672 al Consejo la urgencia de tener preparado un pliego secreto para que gobernase en ínterin una persona de mando mientras se nombrara propietario, "para la quietud de aquellas provincias, escusar disturbios, y regir en justicia». ${ }^{43}$ La situación inestable que vivió el Perú a la muerte de Lemos la manifestó don Francisco de Baños de Herrera, teniente del Regimiento de la Guardia de Perú y maestre de campo, en una carta fechada en 1674 al Consejo de Indias. Este oficial informaba el contexto angustioso que vivía el Perú por la «desunión entre los diez oidores que gobernaban» y la mala providencia de los mismos, quienes se reunían constantemente, pero sin tomar resolución alguna,

pues en cuatro meses después de la muerte del Virrey no se había dispuesto cosa alguna tocante a la defensa que tanto importa; ni en proveer los oficios con pretexto de acomodar en ellos hermanos, sobrinos, parientes, y otras personas, dejándose acomodar a los beneméritos. ${ }^{44}$

Durante las últimas décadas del siglo XVII, se elevaron varias propuestas al Consejo para evitar el gobierno de la Audiencia en caso de ausencia física del virrey en Lima o por la muerte de este. El mismo conde de Lemos tuvo que ausentarse de la Corte limeña varios meses para pacificar las revueltas ocasionadas en Puno, dejando la dirección del reino en su ausencia a su mujer doña Ana Francisca de Borja y Doria, condesa de Lemos y virreina gobernadora del Perú ${ }^{45}$ Consciente de los

\footnotetext{
$42 \mathrm{Ib}$.

${ }^{43} \mathrm{Ib}$.

${ }^{44}$ AGI, Lima, 18, s.f. AGI, Lima, 260, N. 8.

${ }^{45}$ Lohmann Villena 1946: 151-228.
} 
inconvenientes que ello iba a acarrear frente a la Audiencia, dejó una instrucción secreta que limitaba la facultad y soberanía a la virreina, permitiendo que ciertos negocios los determinase con varios oidores como asesores, siempre leales a la causa del virrey. ${ }^{46}$ Entre otros, la virreina acordó los asuntos de guerra junto al oidor y auditor general don Diego Mesía; los de indios, con el oidor don Alonso Hurtado; los de españoles, con don Diego de León, fiscal protector; y, los más arduos, con el presidente don Álvaro de Ibarra. Este acontecimiento resultó relevante en el seno de la Casa Real. La carta remitida por el conde de Lemos a la reina gobernadora doña Mariana de Austria incentivaba la preocupación de que, en caso de ausencia, enfermedad o impedimento del virrey, no había quien rigiese los asuntos políticos con plena autoridad en el Perú. La ausencia del virrey era lo bastante pesada entre los vasallos, quienes concebían su vacío como el abandono del mismo monarca. No existía recelo a un gobierno del tribunal, sino a la falta del soberano en presencia del virrey, eje de todo equilibrio y orden. Esta situación se mostraba no ya solo catastrófica para la buena administración de las provincias, sino que certificaba la inexistencia de todo gobierno, esto es, sin virrey no hay dirección, ni mando, sino un vacío en su totalidad, propicio para los desórdenes públicos y revueltas. ${ }^{47}$

\section{LA AUSENCIA DE UNICIDAD: SINÓNIMO DE QUIEBRA Y DESORDEN POLÍTICO}

La falta de unidad en momentos de interinidad por las audiencias presidenciales trascendió todo el siglo XVII. En consultas de 9 y 10 de enero de 1707 , se propuso al Consejo de Indias aprobar por votos secretos el nombramiento por triplicado para los gobiernos interinos de los virreinatos del Perú y Nueva Espańa, esto es, una lista con tres nombres para tomar el poder en dichos reinos en caso de ausencia o muerte del vicerey. ${ }^{48}$ El temor a una quiebra de autoridad se manifestó no solo respecto a la ausencia de la figura virreinal, sino que se extendió a cada oficio que

\footnotetext{
${ }^{46}$ AGI, Indiferente, 1513.

${ }^{47} \mathrm{Ib}$.

${ }^{48} \mathrm{Ib}$.
} 
mantenía una soberanía plena, sustanciada en la unicidad de su oficio y representación mayestática, como gobernadores, capitanes generales y presidentes de audiencia, principalmente en aquellas jurisdicciones distantes de la capital virreinal y con suficiente autonomía. Estos fueron los casos de las provincias de Filipinas, Panamá, Chile y Buenos Aires, en las que, a falta de gobernador y presidente de audiencia, se produjeron numerosos conflictos y graves desobediencias al alter nos. ${ }^{49}$

En Filipinas, los virreyes de Nueva España indujeron a tener preparado un pliego secreto con los nombramientos de los nuevos gobernadores propietarios, tras los sucesos que causaron la prisión del gobernador Diego Salcedo por parte de la Inquisición en 1669. La ausencia de gobernador ocasionó una gran controversia y desórdenes en la gestión militar en el seno de la audiencia filipina entre los oidores Francisco Coloma y Francisco Montemayor, ya que no tenían definida sus tareas por no competerles asuntos castrenses, lo que suponía una incertidumbre en un territorio alejado del virreinato novohispano, necesitado de una cabeza militar de peso. ${ }^{50}$

Algo parecido se previno para el gobierno de Buenos Aires, como se constata en el memorial tramitado por el sargento mayor del presidio don Juan Cebrián y Velasco. Este oficial aconsejó que a falta de gobernador y capitán general, sirviera el sargento mayor en ínterin gracias a su experiencia militar, previo aviso al gobernador de Tucumán, que asumiría el mando de las provincias del Río de la Plata. ${ }^{51}$ Esta problemática se incorporó posteriormente a la Recopilación de Leyes, ${ }^{52}$ para los casos de vacancia. La mayoría de las cédulas recogidas en la Recopilación sobre este asunto se realizaron entre 1620 y 1670 , lo que indica que fue en estos momentos cuando se intentó solventar uno de los mayores apremios

${ }^{49}$ AGI, Indiferente, 1513. Sobre los disturbios ocasionados en Filipinas tras la ausencia del gobernador y presidente de Audiencia (1664-1668), AGI, Filipinas, 23, R.8, N.27. Recogida en las Leyes de Indias 1681: f. $197 \mathrm{r}$.

${ }^{50}$ AGI, Filipinas, 23, R.10, N.33.

${ }^{51}$ AGI, Indiferente, 582, L.5, ff. 404r-410v.

${ }^{52}$ Leyes de Indias 1774, véanse las leyes 46, 47, 48 y 57 del título 15, del libro 20; y la ley 10 del título $2^{\circ}$, libro $3^{\circ}$. 
administrativos que tuvo la Monarquía católica en las Indias desde el reinado de Carlos V.

De igual manera, la Real Audiencia de Panamá adquirió gran relevancia por ser la «luz de las defensas de las Indias». La preocupación por la salvaguardia y control de la jurisdicción de este tribunal aumentó tras haber sido invadida por los ingleses al mando de Henry Morgan, quien devastó la ciudad, a pesar de las vituallas enviadas por la condesa de Lemos durante la regencia en el virreinato. ${ }^{53} \mathrm{La}$ reconstrucción de la ciudad en la región de Lacón, así como la reposición de los miembros de su audiencia, fue una tarea llevada a cabo por Castellar a su llegada a Tierra Firme de camino a la ciudad de los Reyes, por ser aquellas tierras «la puerta y entrada» de las provincias del Perú, como argumentaron el presidente de Panamá don Alonso de Mercado y el fiscal Sebastián de Velasco. ${ }^{54}$ El tribunal panameño pidió una mayor protección y comunicación con el alter ego, manteniendo la independencia y gran autonomía que acaparaba, así como establecer un trato con el virrey «no como de superior a subordinado, sino como a gran señor»..$^{55}$

La situación crítica que vivían las provincias de Tierra Firme y Nueva Granada era más que evidente. Desde la toma de la ciudad de Portobello en 1668, y la quema de la ciudad en 1671, tuvo que ser nuevamente edificada por Juan Pérez de Guzmán y Gonzaga. El Consejo de Indias señaló la necesidad de proteger esta zona y mantener una mayor comunicación y dependencia con respecto a Lima. Una vez nombrado virrey, Castellar llevó consigo la facultad de visitar y reconocer los castillos y fuerzas militares de ambas provincias, así como reorganizarlas política, jurídica y económicamente. Al producirse la muerte del presidente, gobernador y capitán general de Panamá don Antonio Fernández de Córdoba en 1673, el reino peruano quedó desprovisto de las dos principales cabezas políticas, al fallecer meses antes el virrey conde de Lemos, quedando gobernadas en ínterin ambos tribunales por los oidores, y a merced del enemigo. La audiencia panameńa se encontraba por completo

${ }^{53}$ Freyre 1681: 269-289.

${ }^{54}$ AGI, Panamá, 25, R.2, N.2.

55 Lohmann Villena 1946: 35. 
despoblada de sus oficiales a causas de las defunciones ocasionadas en los últimos años, escenificada en la de su presidente, a lo que se sumó la falta de oficios de depositario general y de los veinticuatro, procuradores, tasadores y oidores. ${ }^{56}$

La autoridad de Castellar se manifestó a su llegada, pues reformó políticamente en su totalidad el tribunal. Comenzó por nombrar a don Alonso de Mercado Villacorta, quien iba provisto por gobernador de Cartagena y que viajó junto al virrey hacia su nuevo puesto, en el que permaneció durante ocho ańos. Junto al virrey, se embarcaron el nuevo gobernador de Guayaquil, Gaspar de Argandońa, y el recién nombrado oidor de Panamá, Fernández Jiménez Paniagua. ${ }^{57}$ No conviene olvidar que el alter ego, por cédula concedida a 10 de mayo de 1643, tenía autoridad para nombrar presidente de Panamá en ínterin. ${ }^{58}$ Esto propició un cambio sustancial en la composición de dicha región que se encontraba completamente asolada políticamente, al tiempo que permitió a Castellar posicionar leales servidores a su causa. De esta manera, se presentaba la autoridad que mantenía el alter nos en su condición de máxima cabeza política, así como la unicidad que congregaba como capitán general y gobernador del reino.

Esta actuación política en la región panameña por don Baltasar de la Cueva, realizada anteriormente por el conde de Lemos y que reformó a su llegada el duque de la Palata en 1681, fue consustancial a la reordenación de las provincias de Tierra Firme por parte del virrey de camino a Lima. Fundamentaba el momento de innovaciones que necesitaban dicha jurisdicción. Ahora bien, en modo alguno las reformas realizadas por el conde de Castellar en esta provincia tienen que ver directamente con las acusaciones tramitadas en su juicio de residencia. Estas apelaban directamente a un conflicto de competencias con el Consulado de comerciantes de Lima, el cual pretendió mantener el monopolio exclusivo sobre las licencias para el paso en mulas recuas del tráfico comercial entre Panamá y Portobello, así como el pago de los derechos sobre

${ }^{56}$ AGI, Panamá, 25, R.2, N.2.

${ }^{57}$ AGI, Panamá, 3, N.119. AGI, Indiferente, 494, L.44, ff. 1r-3r.

${ }^{58}$ AGI, Panamá, 3, N.122. 
la plata, y que el virrey con apoyo del presidente de la Real Audiencia panameña, Alonso de Mercado, intentó arrebatar, procurando al mismo tiempo una mayor implicación en la aportación del Consulado para el mantenimiento de la Armada del Mar del Sur. ${ }^{59}$

Con el fallecimiento del gobernador de Panamá, quedó como presidente en ínterin el oidor don Luis de Losada y Quiñones, quien cometió numerosas irregularidades, entre otras, fraudes de gran perjuicio a la Real Hacienda, así como el nombramiento ilícito como alcalde del crimen y justicia mayor de la casa y aduana de cruces a su hijo don Fernando de Losada, como testificó el visitador don Miguel Francisco de Marichalar. ${ }^{60}$ El problema derivó en que don Luis de Losada no reconocería a otro oficial que no viniera con órdenes expresas del monarca y, por lo tanto, no cedería el poder. La destitución del mismo fue la única solución para que dejase de oficiar como presidente interino. Tal fue la osadía de este ministro, que comenzó la realización de un palacio para sí mismo, lo que los vecinos interpretaron como una «turbación [de] competencias de gobierno entre los alcaldes ordinarios, [y el] sargento mayor del presidio [quedando] sin cabeza que lo govierne todo». ${ }^{61}$ Con la llegada de Castellar, se estabilizó la situación que la audiencia limeña no pudo solventar, tal y como ocurrió en muchas otras jurisdicciones, como la de Nueva Granada, que presentaba las desavenencias de gobierno regida por varios miembros.

Así ocurrió en la ciudad de Portobello «dividido en muchas cabezas su gobierno político y militar y lo que convendrá poner a cargo de una persona sola ambas jurisdicciones». El objetivo era mantener bajo un

59 AGI, Lima, 287, s.f. Rodríguez Vicente 1960: 106-107; Suárez 2001: 353-385 y Caracuel Moyano 1966: 335-343. El mayor de los problemas fue que don Baltasar de la Cueva no supo conciliar sus intenciones gubernativas con el gran poder que habían alcanzado los comerciantes. Para Castellar, la autoridad y potestad regia que emanaban del alter ego no podían ajustarse, ni tan siquiera negociarse con un grupo que basaba su poder en "el comercio como el alma de la república» como indicó el duque de la Palata, teniendo esto poco que ver con los intereses generales de la Monarquía y de los vasallos, protegidos bajo el manto del virrey (Hanke 1980, VI; 261).

${ }^{60}$ AGI, Panamá, 25, R.2., N.3 y N.6.

${ }^{61}$ AGI, Panamá, 25, R.3, N.5. 
solo mando a los tres castellanos de los castillos de Portobello, esto es, al alcalde mayor, que presidía el Cabildo; el capitán de la Compañía del Presidio, capitán de guerra y de la milicia; así como a los tenientes de oficiales reales, ya que estos no reconocieron superior entre ellos y convirtieron a este "cuerpo sin cabeza en aquella republica con notable desconveniencia de Real Servicio». ${ }^{62}$ Hasta tal punto llegó la necesidad de reformar la provincia de Nueva Granada, que el licenciado Sebastián de Velasco, tras la llegada de los ingleses a Portobello en 1668, propuso «se criase virrey en Cartagena» y se concentrara toda la autoridad en una sola cabeza, ratificada posteriormente por los virreyes Castellar y Palata. ${ }^{63}$ Aunque esta última consulta fue rechazada por el Consejo de Indias, Castellar consiguió reconfigurar el centro neurálgico del virreinato peruano - Tierra Firme y Nueva Granada_, reestructurando política, administrativa y militarmente dichas regiones, al tiempo que consolidó una red clientelar que le permitió gobernar en la distancia.

Sobre la Audiencia de Chile, también recayeron ciertas desavenencias que presentaba su demarcación, ya que este tribunal siempre había sido de difícil manejo para los virreyes al mantener gran autonomía. La desunión que existía entre su gobernador, don Juan Enríquez y algunos ministros de la Audiencia, en especial el oidor don Juan de la Peńa Salazar, provocaron diversos enfrentamientos que tuvieron su origen en «los afectos parciales de cada uno», a principios del gobierno de Castellar. Así lo notifica el virrey en una carta al Consejo el 1 de septiembre de 1676, en el que anunciaba la certeza de la «dura desunión de los ministros [...] y los demás de las audiencias de este reino, obispos, corregidores, y demás sujetos de la primera graduación». ${ }^{64}$ Ello se debía a la intromisión violenta de los virreyes y otros oficiales civiles en los votos de los capitulares para elegir a las autoridades provinciales, a pesar de que lo tenían prohibido. Castellar ordenó a los corregidores que se ajustasen a no entorpecer dichas elecciones manteniéndolas libre de toda acción. La intermediación del virrey en este conflicto fue decisiva para calmar

${ }^{62}$ AGI, Panamá, 25, R.4, N.17.

${ }^{63}$ Jiménez Castillo 2016: 25-62.

${ }^{64}$ AGI, Lima, 75 , s.f. 
la administración en la provincia real chilena. Así se ejecutó con la visita efectuada por fray Antonio de Ozerín, provincial de San Francisco de la provincia de Lima, enviado por Castellar. Este servidor del alter ego disuadió las diferencias entre el gobernador don Juan Enríquez, de naturaleza «blando y apacible» fiel y leal servidor del monarca, quien otorgó limosnas y reedificó la iglesia de la Concepción, como aseguró el obispo don fray Francisco de Loyola Vergara, con el oidor don Juan de la Peña Salazar, ministro «limpio, justificado y de particular celo y atención al Real Servicio». Según Castellar, para «afianzar más la tranquilidad que hoy se goza», era preciso «sacar» de la audiencia chilena tanto al oidor don José de Meneses como al fiscal don Francisco de Cárdenas para ser trasladados a la de Panamá. Al tiempo, don Nicolás del Campo oidor de Panamá y cuñado de Cárdenas, pasó a servir la fiscalía de Quito, con el fin de evitar «algunos inconvenientes» a la hora de gobernar. ${ }^{65}$ El monarca aceptó nombrar a Cárdenas como fiscal de la Audiencia de Panamá, reestructurando en parte las provincias de Chile, a su vez que el virrey aseguraba férreos lazos con el tribunal panameño, ${ }^{66}$ que le valió posteriormente las acusaciones sobre su gobierno arbitrario por parte de las facciones contrarias al virrey. ${ }^{67}$

La complejidad para gobernar esta región se manifestó en una carta enviada por el virrey Castellar a 18 de febrero de 1678, justo antes cumplirse su eclipse político. En ella, suplicaba al monarca suspender la orden dada sobre la nueva composición territorial y administrativa

${ }^{65} \mathrm{Ib}$.

${ }^{66}$ Jiménez Castillo 2019: 207-233.

${ }^{67}$ Suárez Espinosa 2017: 339-350. Si bien el conde de Castellar fue el primer virrey expulsado de la Corte de Lima, esto no se debió a una mala gestión de su gobierno, como indican las acusaciones de su juicio de residencia; más bien manifestó el punto de inflexión de una práctica de gobierno áulica y absoluta por parte de los virreyes, y no a una causalidad privativa de los hechos civiles ocurridos en el seno del reino del Perú. A este proceso se le ha denominado de reconfiguración política de la Monarquía Católica encabezada por el infante don Juan José de Austria, quien transformó políticamente todos los virreinatos, como ocurrió en el reino de Sicilia, Nápoles o Cataluña, los cuales perdieron en 1678 la capacidad de otorgar mercedes entre sus parientes, criados y allegados, acusados de una excesiva liberalidad y concesión, la misma imputación por la que fue acusado el virrey Castellar. Al respecto, véase Arrieta Alberdi 1994: 515-518. 
otorgada a las provincias de Chile. Esta consistió en agregar la jurisdicción de la plaza y puerto de Valdivia al gobierno de Chile, ya que tan solo distaban cuarenta leguas de la ciudad de la Concepción, donde residía el gobernador y capitán general del reino chileno. Ello significó la p" erdida del control y superintendencia de la plaza a los virreyes del Perú, lo que obligaba a acudir a las asistencias y demás géneros del situado de aquel presidio, donde se proveía todo lo necesario mediante la Caja Real de Lima, como quedó ejecutado por cédula de 30 de marzo de $1676 .{ }^{68}$

De esta manera, el monarca resolvía los nombramientos de aquel puesto a través del Consejo de Cámara y Junta de Guerra de Indias bajo consulta previa del gobernador chileno, proponiendo los soldados más beneméritos en grados y servicios para premiar a los más adelantados «en el valor y experiencias militares», siempre que vacare el puesto y plaza de Valdivia. Castellar alzó su rogativa al Consejo, dado que no se le había realizado consulta alguna para tal cambio y reducción de su poder, pidiendo solo consejo a los nuevos gobernadores propietarios e interinos del reino de Chile. A estos acusaba el virrey que más que defender la gobernación, el único fin que perseguían era el de llenar «la ambición de hacer los proveimientos de gobernador y demás cavos que es el único blanco a que han mirado». ${ }^{69}$ La reserva que hizo el monarca para los nombramientos de sargento mayor, castellanos, veedor y capitanes enfatizó la autonomía de los gobernadores de Chile para acomodar a sus servidores. El virrey quería que las designaciones efectuadas no fueran por proposición única de los gobernadores chilenos, ya que anteponían «los de su devoción [...] con desconsuelo universal de aquella milicia que precisamente se hallara obligada a retirarse por no tener más premio ni comodidad ${ }^{70}$.

El hecho de que Valdivia perteneciera jurisdiccionalmente a Chile no era sino una «suposición siniestra» en opinión de Castellar, dado que la unidad de este gobierno se forjó durante el mando del alter ego peruano don Pedro Álvarez de Toledo y Leiva, primer marqués de Mancera, de

${ }^{68}$ AGI, Lima, 77, N.116.

${ }^{69} \mathrm{Ib}$.

${ }^{70} \mathrm{Ib}$. 
1639 a 1648. Fue este virrey quien fortificó y pobló la plaza después de que la armada holandesa la ocupara, y ensanchó su espacio para hacer frente a los indígenas rebeldes. De la ciudad de la Concepción, no había más de cuarenta leguas y de Santiago, ochenta; sin embargo, pocas veces asistían los gobernadores a dicho presidio al tener la obligación de residir en ella unos seis meses al ańo, como ocurría en otras jurisdicciones de la Monarquía. La plaza de Valdivia, como reflejó el virrey en su memoria de gobierno, era la

escala principal a este reino por los estrechos de Magallanes y Maire, y la más apetecida por los enemigos por la facilidad con que desde ella podían lograr hostilidades en el Perú, Chile, y las costas de Guatemala y Acapulco, procuró mi desvelo tenerla siempre abastecida y defendida de víveres, gente, armas, municiones y de buenos cabos y gobernadores. ${ }^{71}$

En esta carta, Castellar reflejaba su obstinación para evitar que se provocase una oclusión del poder que tenía el virrey en Chile, ya que «todas las provinzias, ciudades y pueblos del Perú lo son en que el govierno de Baldivia corra como hasta aquí por los virreyes sin otra intervención ni limitarles la jurisdición que han tenido». ${ }^{72}$ Esto supuso una disputa frente a la mayor autonomía del gobernador chileno, produciéndose una restricción de la autoridad del virrey que no tenía en ninguna otra provincia del reino. Consideraba provechoso que el gobernador de Chile tuviera arbitrio y mano en la plaza de Valdivia, siempre que estuviera bajo la potestad del virrey. De lo contrario, se vería privado el gobernador de los socorros y castigos que hacía llegar Castellar desde Lima. Así se defendió el alter nos, remitiendo al monarca que desde que llegó al solio virreinal había mandado trescientos cincuenta hombres, sin una gran repercusión en las sanciones sobre los delitos y buena administración, debido a la mala gestión del gobernador don Antonio de Isasi. ${ }^{73}$ Finalmente, recomendaba proveer dichos oficios en soldados que no solo hubiesen militado en la guerra de Chile, quizás para evitar

${ }^{71}$ Hanke 1980, V: 122.

${ }^{72}$ AGI, Lima, 77, N.116.

${ }^{73}$ AGI, Contratación, 5442, N.136. 
parentelas, sino a los que poseyesen una experiencia internacional, como lo reencarnaba Francisco Delso y Arbizu.

Pocos meses después de llegar al virreinato, el conde de Castellar nombró a este oficial como gobernador de Valdivia, concretamente el 19 de marzo de 1675, debido a su gran experiencia en las galeras de Nápoles, Sicilia, el ejército de Cataluña, en la Armada del Océano y, finalmente, como sargento mayor del presidio del Callao. ${ }^{74} \mathrm{Su}$ sucesor fue Diego de Martos, quien pasó a las Indias como gobernador de la provincia de Chucuito, a quien el virrey le encontró sirviendo como maestro de campo general de todas las milicias de gente de guerra del reino del Perú, esto es, encargado de la defensa, seguridad e invasiones de enemigos del reino, nombramiento realizado por la audiencia limeña tras la muerte de Lemos. ${ }^{75}$ Fue Castellar quien le encargó ocupar la plaza de Valdivia, con el objeto de mantenerle más de dos años — provisión regular de estas plazas - para afianzar con su valor y experiencias militares la defensa de las costas del Mar del Sur expuesta a los ataques de los ingleses. ${ }^{76}$

En dicho contexto, le llegó al virrey la carta del gobernador de Chile, don Juan Enríquez, donde le avisaba del nombramiento del nuevo gobernador de Valdivia en don Francisco Hernández de Cifuentes, reservándose desde ese momento la provisión de aquel puesto y plaza, sin consultar y concurrir con el informe del virrey, lo que desproveía al recién nombrado don Diego de Martos. La insistencia del virrey sobrepasó los límites de la prudencia al proponer al Consejo de Indias suspender la posesión del nuevo gobernador hasta que el monarca estuviera mejor informado de la situación sobre aquella región. ${ }^{77}$ No obstante, fue firme el rechazo a tal propuesta desde la Corte de Madrid.

${ }^{74}$ AGI, Indiferente, 127, N.97.

${ }^{75}$ AGI, Contratación, 5794, L.2, ff. 310v-313v.

${ }^{76}$ AGI, Lima, 77, N.116.

${ }^{77} \mathrm{Ib}$. 


\section{LOS PROBLEMAS DE UN VIRREINATO EN ÍNTERIN: LA MULTIPLICIDAD}

\section{FRENTE A LA UNICIDAD}

A finales del siglo XVII, los intentos por eliminar los gobiernos en ínterin fueron unas de las reformas más apremiantes. Desde las Indias, por parte de los virreyes, oidores y oficiales reales, como desde el Consejo de Indias en Madrid, se enunciaba la exigencia de regir bajo orden y unidad, congregada en el virrey como cabeza primigenia del reino. Los gobiernos interinos se caracterizaron por la falta de conformidad y potestad en los dictámenes efectuados por los oidores, así como por «muchas dependencias de la Audiencia, unas de sangre y amistad y otras de diversas pasiones ${ }^{78}$ que mantuvo el tribunal limeño a la muerte del conde de Lemos en 1672. Ello reflejaba la estabilidad que asignaba la figura virreinal a los reinos, como quedó patente tras la muerte del virrey don Diego de Benavides y de la Cueva, conde de Santisteban. Estas transiciones siempre fueron consideradas de fragilidad política, aprovechadas para organizar revueltas y turbación pública, como las ocurridas al tomar el mando la Audiencia de Lima, cuando se produjo un intento de sublevación por parte de los indios y otros forasteros de la región de la ciudad de Los Reyes. Esta conjura fue debidamente castigada por el tribunal al condenar a pena de muerte a los ocho cabecillas de tal movimiento. A pesar de la buena reacción y apaciguamiento del tribunal limeño, lo cierto es que el gobierno interino en sus manos siempre mostró incertidumbre y falta de precisión, como la misma Audiencia se encargó de informar al Consejo de Indias, apremiando para nombrar por vía secreta la vacante de virrey. ${ }^{79} \mathrm{Si}$ bien es cierto que no existe una relación directa de causalidad entre las ausencias de virreyes y los levantamientos contra las autoridades regias, la falta del alter ego motivó que se produjesen situaciones inestables. La llegada de un tribunal de justicia al poder sustentaba una mayor defensa de los intereses locales. ${ }^{80}$

${ }^{78}$ AGI, Indiferente, 1513, s.f.

${ }^{79} \mathrm{Ib}$.

${ }^{80}$ Burkholder y Chandler 1984. 
Otro de los problemas asociados a la interinidad se debió a la gran cantidad de oficios entregados entre sus allegados y la dificultad de tomar una resolución unívoca. Según anunciaba la última consulta al monarca por parte del Consejo de Indias, elaborada por alguna facción contraria al tribunal, los oidores dilataron la noticia del fallecimiento del conde de Lemos para «estar los oidores sustituyéndole y con mayor autoridad y mano con que no es bien se le deje a todos para que puedan obrar llevándose de sus afectos en perjuicio de aquellos vasallos estando el recurso de las partes tan remoto y distante de la persona de V.M.». ${ }^{81} \mathrm{Un}$ caso evidente fue el de la presidencia de don Álvaro de Ibarra — primer criollo en ocupar dicho oficio-, que a pesar del reconocimiento que tenía por haber realizado la visita de la Audiencia a la muerte de José de Salcedo y los castigos que efectuó en Laicacota, «le tenían por apasionado y afecto a la nación Vizcaína». ${ }^{82}$

La Audiencia de Lima nombró a un total de nueve allegados en corregimientos relevantes del reino con el fin de afianzar a oficiales muy vinculados a los intereses de los oidores. Esto confirma que la autoridad no se basaba en la propiedad individual de cada agente, sino que se constituía en una actuación fundamentada en grupos de poder que formalizaban y articulaban estos espacios. ${ }^{83}$ Esta política sirvió para hacer frente a las futuras redes clientelares del virrey conde de Castellar, así como forma sustancial para regir el reino por parte del tribunal. Fue el caso de Alonso de la Cueva, nombrado corregidor de Huailas entre 1672 y 1674, primo del oidor limeño Diego Cristóbal Messía; o el de don Andrés Gutiérrez de Rocas, casado con la sobrina del juez Ibarra. Lo relevante es que estos nueve provisionados estaban íntimamente emparentados con los oidores de Lima, ${ }^{84}$ además de ofrecer oficios de gran relevancia en la nueva composición militar del reino, ministerios

\footnotetext{
${ }^{81}$ AGI, Indiferente, 1513, s.f. Algo parecido rescataba Aristóteles en boca de Empédocles cuando arguyó que «donde nacieron muchas cabezas sin cuello» posteriormente vienen a componerse por la fuerza de la amistad» (Aristóteles 2014b: 128).

82 AGI, Lima, 11.

${ }^{83}$ Bertrand 2005.

${ }^{84}$ AGI, Lima, 62.
} 
que generalmente recaían sobre el alter ego, como gobernador y capitán general del mismo. El tribunal posicionó a un teniente de maestro de campo general del reino, un sargento mayor, un gobernador general de caballería, y a dos capitanes de la Real Armada. ${ }^{85}$

La Audiencia de Lima puso a soldados con una gran experiencia militar y apartó a aquellos que carecían de la misma o no se encontraban en su grupo de favor, como fue el caso del oficio de teniente y maestro de campo general del reino, ocupado por Felipe Romana, criado del virrey conde de Lemos, nombrando en su lugar a Pedro de Montoya, según los méritos que le avalaban. A Francisco Delso, de gran experiencia militar, que vino a las Indias acompańando al virrey conde de Lemos en 1667, quien le nombró sargento mayor del presidio y fortificaciones de Valdivia desde el 9 de febrero de 1673, pasó por nombramiento de la Audiencia a sargento mayor del presidio del Callao y del reino del Perú, desbancando a Felipe de Zavala y Alcedo quien ocupaba el puesto. Sirvió Francisco este oficio hasta la llegada de Castellar, siendo reformado el 13 de octubre de 1674 tras nombrarle gobernador de Valdivia. Este fue uno de los militares de mayor confianza tanto para la Audiencia, como para Castellar, acomodando a su hermano Martín Delso y Arbizu en el corregimiento de Sicasica en 1675, consolidando así a otra gran familia de poder en el virreinato.

Entre otros, un último caso fue el de Fernando de Sotomayor, sargento de la compañía del capitán de don Álvaro de los Ríos y Berris, hermano de Juan de Sotomayor, a quien se le concedió un corregimiento en Calca y Lares, justo a la llegada de Castellar. Este virrey sabía de la determinación y estrechos vínculos que mantenían en el virreinato, los cuales tuvo que recompensar y respaldar para mantener su favor. No obstante, el cuadro militar bajo Ibarra al frente de la audiencia interina quedó completada con los nombramientos de Hernando de Rivera como sargento mayor de batalla; don Diego de Martos, como maestre de campo general que 
mantenía el corregimiento de Chucuito; y por último, a Miguel de Noroña, como gobernador de la caballería, corregidor de Cuenca. ${ }^{86}$

Finalmente, una de las reformas que realizó la Audiencia interina fue sobre la composición de la compañía de caballos de la guardia del virrey, con el fin de reducir la capacidad de la misma. Esta se aprobó por el Consejo de Indias debido a las necesidades hacendísticas, que repercutió en una disminución de sus sueldos y el prestigio que envolvía y elevaba al virrey. Según Castellar, esto suponía una quiebra en la defensa del reino, ya que esta compañía era la única salvaguardia para oponerse a invasiones enemigas. Para el virrey, no solo convenía mantener la leva de trescientos caballos que correspondían a las seis compañías de a caballo, con sus capitanes, primeras planas y cincuenta hombres de cada una, sino crear otra compañía de infantería con trescientos soldados. ${ }^{87} \mathrm{La}$ reforma de la compañía de la guarda del virrey fue un motivo de excedencia en su composición y como tal a la del alter ego extralimitando su ostentación, más que una necesidad militar o defensiva. Su número había aumentado considerablemente, aunque existía plena conformidad en su mantenimiento, ya que nunca se llegó a pensar en derogarla, por dos motivos. En primer lugar, las revueltas ocasionadas en Puno durante el gobierno de Lemos pudieron ser atendidas con rapidez para sofocarlas; en segundo lugar, los dos intentos de asesinato a Castellar. No obstante, el entendimiento entre el tribunal limeño y el virrey se hizo necesaria en asuntos militares y, en ocasiones, colaboraron mutuamente. Así se observa en la formación del Real Acuerdo de 1 de agosto de 1678 con don Melchor de Liñán y Cisneros como virrey-arzobispo interino, lo que confirmaba la potestad a los virreyes para nombrar oficios castrenses. No obstante, el Consejo la revocó prohibiendo tal medida, con el fin de ajustarse a las cédulas emitidas de 1 de febrero y 3 de marzo de 1678, que limitaban el poder de los virreyes. ${ }^{88}$

Las últimas reformas señaladas ocasionaban un problema fundamental en la administración del reino y, sobre todo, en términos de autoridad.

${ }^{86}$ AGI, Lima, 103, s.f.

${ }^{87}$ Mss. 22999, Biblioteca Nacional del Perú [en adelante BNP]; AGI, Lima, 74, N.129.

${ }^{88}$ AGI, Lima, 575, L.29, ff. 197r-198v. 
El poder como tal tiende a la concentración, a la unidad y centralidad, es decir, se busca a sí mismo. ${ }^{89}$ Esto no quiere decir que el poder no pueda ser expansivo y fragmentario — relaciones clientelares—, sino que la división y desmembración del órgano político o militar que ejerce el poder de manera indiscriminada es contrario a la autoridad, dado que esta se realiza en la unidad y por ella «se dice que cada cosa es una». ${ }^{90}$ En el caso virreinal, la unidad no solo quedó patentada en la persona física del virrey, eje por el que el sistema tiene su punto gravitatorio, sino en la composición de todo el cosmos que en torno suyo hacía de él la máxima fuente de autoridad, esto es, su casa como forma de organización política y en las relaciones personales.

La teoría de la unicidad como fuente inalterable, permanente y homogénea tiene su origen en el atomismo griego de Leucipo y Demócrito; y fue heredada y aplicada a la teología medieval, según la cual la pluralidad de las cosas responde a una misma fuente común: su ser creador, que congrega la unidad. Así fue considerada por Diego Saavedra Fajardo, para quien «la presencia de los príncipes es fecunda, como la del sol. Todo florece delante della, y todo se marchita y seca en su ausencia». ${ }^{91}$ Esta cultura simbólica y visual permitió congregar la unidad y autoridad del poder en el cargo de virrey como «oficio de cabeça». ${ }^{92}$ Así lo destacaban grandes teóricos del pensamiento político moderno, como Giordano Bruno o Nicolás Maquiavelo, quienes advertían que era preciso que sea solo uno el que organice o reforme la república, evitando la «diversidad de opiniones». ${ }^{93}$ Este asunto fue de constante preocupación en el seno del Consejo indiano, tras las diversas consultas que hicieron llegar al presidente don Pedro Portocarrero del Manzano, conde de Medellín, quien meditaba realizar poner fin a las ausencias de virreyes, pues para un caso tan frecuente como este, era necesario llevar nombrado un alter ego en ínterin hasta la llegada del propietario para asegurar la paz en el

\footnotetext{
${ }^{89}$ Han 2016: 153.

${ }^{90}$ Gundissalinus 2015: 103.

${ }^{91}$ Saavedra Fajardo 1999: 385.

92 Solórzano Pereira 1648: 65-112.

${ }^{93}$ Maquiavelo 2018: 67-71 y 189.
} 
reino. Esta duda consistía en reestructurar una política heredada desde la emisión de la real cédula de 19 de marzo 1550 por Carlos V, en la que en casos de desaparición de los virreyes sucedieran las audiencias con plena facultad para gobernar. ${ }^{94}$

Este problema se alargó y quedó pendiente en el Consejo de Indias durante décadas, lo que ocasionó que oidores, gobernadores y capitanes generales alzaran la voz reclamando el gobierno de los virreyes frente a los interinatos de las audiencias. Fue el caso del capitán y oidor decano de Santa Fe, don Mateo de Mata, ${ }^{95}$ quien envió una carta el 15 de diciembre de 1678, una vez destituido Castellar. Para el letrado, que tomara el gobierno la Audiencia en ínterin significaba «la total aniquilación de las Indias», prefiriendo «el desconcertado y tirano gobierno de un presidente, que no el más acertado y benigno de una Audiencia». Según su experiencia, cada vez que se ausentó el virrey se había producido numerosas extorsiones y malos tratamientos, asemejando estas situaciones al triunvirato ocurrido en la antigua Roma. ${ }^{96}$

De lo contrario, el gobierno interino debiera desempeñarlo un prelado, como ocurrió en México cuando gobernó el arzobispo Payo Enríquez de Ribera desde 1673, a causa de la grave enfermedad que sufrió el virrey don Pedro Nuño Colón de Portugal y Castro, que falleció al poco de su llegada. En último caso, se debería recurrir al oidor decano, pero siempre que este gobernase la totalidad de la Audiencia a título personal — unificando los asuntos civiles y militares-. Desde el Consejo de Indias, se expidió que las soluciones que aplicaban a las vacantes de virreyes en los reinos de Italia no se podían efectuar para las Indias. Entre otras razones, se debía a la gran distancia que la separaba de Castilla, como argumentó previamente el conde de Lemos, pero sobre todo por la falta de «sujetos

${ }^{94}$ Estas órdenes se repitieron por cédulas de 19 de octubre de 1586 tras consulta del virrey del Perú Martín Enríquez de Almansa conde de Villardompardo; y otra de 20 de noviembre de 1606 dirigida a la Audiencia de Panamá por haber recibido órdenes de la Audiencia de Lima gobernando por muerte del virrey don Gaspar de Zúñiga Acevedo y Velasco conde de Monterrey.

${ }^{95}$ AGI, Indiferente, 495, L.45, ff. 104v-105v.

${ }_{96}$ AGI, Indiferente, 1513. 
de la calidad y partes necesarias para estos empleos [...] que es la causa porque siempre se ha seguido la disposición dada desde su descubrimiento", tanto en México como en Perú. No obstante, Mata pretendió infundir al Consejo indiano la unidad como forma de gobierno con el fin de evitar perjuicios, ya que resultaba mucho mejor lo que podía ser realizado por uno que por muchos, ${ }^{97}$

pues nunca las tiranías de uno llegan a ser tantas como las de muchos, a más de que gobernando uno solo tiene siempre el freno de que a él solo se le ha de echar la culpa de lo mal obrado para contenerse en los desafueros y espuela que le incita a obrar bien siendo solo el que a de llevar la gloria y el premio confundiéndose todo esto en el govierno de muchos oyéndose solo los lamentos de los súbditos por las opresiones y tiranías que han padecido sin que se pueda saber quién las ha causado porque se suelen siempre despachar Visitas para serenar las tempestades de un gobierno de muchos y las más veces o todas nada se remedia. ${ }^{98}$

Todos los memoriales sobre la gobernación interina enviados al Consejo indiano fueron igualmente analizados en el seno del Consejo de Estado. A este tribunal, se remitió relación por parte del conde de Fuensalida para el presidente don García de Haro, conde de Castrillo, el 13 de septiembre de 1668, por las inconveniencias de llevar título en ínterin de gobernador y capitán general de los Países Bajos de Flandes, debido "a la autoridad con que se debe estar en aquel puesto" y la diferencia que tenía en los despachos que se le dieron respecto a los que poseyeron el título de gobernadores propietarios, como fue a don Luis Francisco de Benavides y Carrillo de Toledo, tercer marqués de Caracena, o el caso de don Francisco de Melo. Según esta consulta, el puesto en ínterin influiría en el gobierno y «humor de aquellos naturales», pues era más complejo el tratamiento y gobierno de dichos territorios. ${ }^{99}$

\footnotetext{
${ }_{97}$ Alighieri 2009: 30.

${ }_{98}$ AGI, Indiferente, 1513.

${ }^{99}$ Archivo Histórico Nacional, Estado, 1641, s.f. Al tiempo que se tramitaba esta consulta, en Lima el virrey conde de Lemos tuvo que dejar a su mujer la condesa como virreina en ínterin, al mando de todo un reino, con ciertas limitaciones y reparto de
} 
Los últimos virreyes peruanos del siglo XVII alzaron la voz a la Corona con el fin de resolver este asunto. Así lo ejecutó don Melchor de Navarra, quien formalizó la importancia que tenía nombrar y resolver cuanto antes el puesto de virrey al ser vacante la Audiencia, porque «cada día nos ejecuta a todos la muerte, y conviene que se halle prevenido este caso, que a ningún virrey le quitará un día de vida el saber que está dada providencia para cuando llegue el de su muerte». ${ }^{100}$ A la llegada de don Baltasar de la Cueva, conde de Castellar a Lima en 1674, se inició una serie de transformaciones en el seno de la audiencia limeña, tras los desórdenes que esta misma había dejado, lo que derivó en una situación interna crítica. ${ }^{101}$

\section{LA REFORMA DEL CEREMONIAL COMO ELEMENTO DE JERARQUIZACIÓN Y ORDEN}

Entre 1672 y 1674, la audiencia interina modificó ciertas formas viceregias de gobierno para adquirir competencias que le permitieran aumentar su potestad. ${ }^{102}$ La difícil situación encontrada por Castellar fue descrita por Lohmann Villena:

los oidores se limitaron a conservar, mal y trabajosamente, el estado que a fines de 1672 manifestaba el virreinato. Duró año y medio esta interinidad, tan funesta como la de todas las audiencias, hasta que el conde de Castellar vino a restablecer cierto orden y disciplina en la confusión que amenazaba con invadir nuevamente el país. ${ }^{103}$

funciones, aunque con plena autoridad que le confirió el virrey (Mendiburu 18741890, II: 73).

${ }^{100}$ Hanke 1980, VI: 111.

${ }^{101}$ Las primeras medidas que puso en marcha fueron la alteración de los componentes del tribunal, una revisión económica de todas las cajas de dicha ciudad, la reestructuración militar del reino, al tiempo que consolidaba el poder bajo su mandato con el nombramiento de sus criados y allegados en los puestos más relevantes del virreinato. ${ }^{102}$ La responsabilidad que recaía sobre dicho tribunal no se correspondía con la autoridad que pudiera implementar en las órdenes tramitadas a gobernadores, corregidores o presidentes de otras audiencias. Ello se debe a la autonomía que Chile, Quito o Charcas habían adquirido frente a la de Lima, las cuales no reconocían a esta última como cabeza superior, dificultando aún más si cabe dicha gestión (Hanke 1980, VI: 100).

${ }^{103}$ Lohmann Villena 1946: 393. Las fuentes utilizadas por Lohmann Villena son: «Romance sobre el Estado del Perú a la muerte del Conde de Lemos» (1674) y las Cartas 
La delegación en asuntos de justicia que mantenía la Audiencia la incapacitó para ejercer tareas gubernativas, religiosas o militares, dada su inexperiencia, lo que avivó numerosas discrepancias a la hora de tomar una decisión instantánea en circunstancias de peligro, así como en reformas civiles, siendo el ceremonial la manifestación política por excelencia. ${ }^{104}$

Según Castellar, las transformaciones ocasionadas por la Audiencia de Lima consistieron en la apropiación de numerosos privilegios administrativos. El virrey comenzó por reajustar la hacienda, asistiendo a los Acuerdos de la Real Audiencia, Sala del Crimen y Tribunal de Cuentas para cerrar los expedientes de negocios que llevaban años sin resolverse. Fue durante estas reuniones donde comprobó y excusó a los señores oidores de ciertas prerrogativas concedidas por el conde de Lemos, pero que Castellar no estaba dispuesto a consentir, como las acontecidas en el ceremonial. Estas medidas bien pudieran parecer la tónica general en el uso simbólico y escenificación del poder en el virreinato, si no fuera porque estos acontecimientos se dieron en un momento de reconfiguración del virreinato y de transfiguración del poder virreinal, en el que se pretendió que la ostentación áulica de los virreyes se viese considerablemente limitada, hasta presentarse como oficiales ordinarios. ${ }^{105} \mathrm{El}$ virrey don Melchor de Navarra (1681-1689) advirtió en su Relación de gobierno la dificultad que tenían los virreyes para gestionar el reino junto al tribunal, ya que los oidores luchaban por acaparar altas cuotas de poder, en un contexto en el que "gobiernan todos y quieren gobernar al virrey». ${ }^{106}$

Los gobiernos interinos de las audiencias fueron oportunidades para la ampliación de sus competencias y privilegios. ${ }^{107}$ Estas conjeturas y presiones en los ceremoniales y fiestas públicas suponían una lucha sobre el espacio jurisdiccional, derecho concedido por el monarca. ${ }^{108}$

y expedientes de personas seculares del distrito de aquella Audiencia (AGI, Lima, 431, s.f. 1674-1702).

${ }^{104}$ Muro Romero 1975: 93-174; Solórzano Pereira 1648: 763.

105 Solórzano Pereira 1648: 873-884.

106 Ib.: 260.

107 Merluzzi 2016: 315-344.

108 Pérez Vejo 2018: 109-134. 
Suplantar un lugar en una ceremonia implicaba infringir el orden establecido en el sistema de códigos simbólicos, al no corresponder con la naturaleza política delegada y representativa a cada oficio. ${ }^{109}$ El soberano, como benefactor y hacedor de toda realidad y substancia política, dispensó como ser remanente la existencia a todo servidor y organismo, dotándole de jurisdicción, esto es, "primero existe el derecho; el poder político viene después». ${ }^{110}$ Por ello, cualquier atribución independiente a la voluntad de aquel que rige los reinos fue considerada no solo como ilegítima, sino perturbadora del orden social, dado que aceptar dicha fisura suponía desobedecer el orden impuesto por aquel que vertebraba la realidad. Jerónimo Castillo de Bobadilla argumentó que la destrucción de la República «nace de la perturbación de los oficios». ${ }^{11}$

Una de estas transformaciones realizadas durante la interinidad por la audiencia limeña y aprobada durante el gobierno del conde de Lemos fue que los ministros togados pudiesen eludir su asistencia a las fiestas religiosas, siendo solo posible las de tabla. ${ }^{112}$ Durante el mandato de este virrey, en cada salida pública solía llevar a varios jueces junto a él, cuatro en los estribos y otros dos en la delantera, obviando la diferencia entre los oidores, alcaldes de corte y fiscales. ${ }^{113}$ El virrey Castellar confesaba por ello «gran novedad la forma como el motivo por no adecuarse en nada a la razón ni al estilo que se practica en los demás reinos, consejos y cancillerías de S.M., aunque no en todos es uno lo mismo». ${ }^{114}$ Castellar juzgaba conveniente respetar y seguir la etiqueta de las chancillerías de Granada y Valladolid, ya que comprendían la más alta igualdad dada a los presidentes de audiencias en sus acompañamientos de tabla.

\footnotetext{
109 Hespanha 1993: 85-121.

${ }^{110}$ Grossi 2003: 25.

111 Castillo de Bobadilla 1649: 740.

${ }^{112}$ La voz tabla para la época moderna en América refería a las fiestas obligatorias, tanto religiosas como civiles «De las precedencias, ceremonias y cortesías» (Leyes de Indias 1774: libro III, título XV).

${ }^{113}$ AGI, Lima, 73, N.16. Por cédula de 10 de octubre de 1657 se dispuso de que solo fuesen en el estribo del coche.

${ }^{114}$ Hanke 1980, V: 70.
} 
Esto demostraba la «tanta superioridad de los virreyes [que] se muestran sentidos, de que no se les acompañe a las partes donde son convidados». ${ }^{115}$

El motivo por el que esta cuestión adquiere gran relevancia se debe a que Castellar defendió el honor y puesto que representaba como magnificencia regia y "decencia que requiere su persona y Casa, y el puesto que ocupa», esto es, la imagen que se había desarrollado como «virreyes absolutos». ${ }^{116}$ Así lo refleja el séquito y ostentación con el que fue nombrado, además de los tres salarios que conservaba en propiedad: el de oficio de virrey; consejero del Consejo, Cámara y Junta de Guerra de Indias, además de los 3467 ducados de vellón anuales (2318 ducados de a once reales de plata en indios vacos en el Perú), que le situaron en el reino de Nápoles durante su nombramiento como embajador en Venecia para el tiempo que sirviese fuera de Espańa. A ello que hay que añadirle la compensación por los gastos ocasionados en su retraso a Lima, debido a la tardanza en su salida y el tiempo que permaneció en Tierra Firme, estipendio que se incorporó a su salario. ${ }^{117}$ Las modificaciones en el ceremonial fueron interpretadas por Castellar como la quiebra del orden jerárquico en el reino, en la que un virrey alcanzaba el culmen de la majestuosidad en América. Por ello, este debate no debe entenderse como el enfrentamiento entre un virrey con un poder excelso frente a una audiencia interina que pretendía estabilizar sus intereses en el Perú. ${ }^{118}$ El contexto derivado de esta situación es mucho más amplio y solo tuvo resonancia a posteriori, esto es, durante su juicio de residencia en el que

${ }^{115}$ AGI, Lima, 73, N.15. Desde 1639, se permitió sin autorización del monarca que el Cabildo limeño les acompañara a caballo en todas las fiestas que fueren a la Iglesia; o permitir a los oidores y fiscales de manera particular acudir a fiestas particulares y entierros (AGI, Lima, 109).

${ }^{116}$ Sobre la pomposidad y comitiva de la entrada de Castellar y su recibimiento, fue la «cosa [más grande] que no se ha visto otro tanto en Lima» (Mugaburu 1918: 59).

${ }^{117}$ AGI, Indiferente, 495, L.45. AGI, Lima, 11, s.f. El goce anual del conde de Castellar por las plazas del Consejo, Cámara y Junta de Guerra de Indias ascendían en su totalidad 1.548.862 maravedís de plata, en concepto de salario, cerería, dulces y otros estipendios para fiestas y ceremonias, acumulando uno de los mayores patrimonios del virreinato $y$, por lo tanto, de jerarquía.

${ }^{118}$ Henshall 2010: 33. 
desde Madrid se pretendió aprovechar estas pugnas para debilitar el poder de los virreyes, orquestado por don Juan José de Austria. ${ }^{119}$

Las formas expresivas en público durante el siglo XVII adquirían autoridad de facto, dado que «los discursos están formados por signos», ${ }^{120}$ principalmente en estas sociedades donde el concepto de poder y autoridad estaba íntimamente relacionado con la exhibición pública. ${ }^{121}$ De esta manera, las palabras de Castellar adquirieron todo su sentido cuando argumentó la premura de evitar «la profanidad y exceso que había introducido la vanidad y emulación en los túmulos y coches que se iban introduciendo, malbaratando por este infructuoso desperdicio aun la hacienda que no se tenía», ${ }^{122}$ bajo un claro auspicio en limitar la representatividad y el poder de ciertos oficiales. Otro aspecto que modificó fue la figura del escribano de cámara, que despachaba sentado y cubierto con sombrero en los acuerdos, como lo llevaban haciendo desde más de cien años. Los alcaldes ordinarios que por 1675 ocupaban tal oficio eran don García de Híjar y Mendoza, y el capitán don Pedro Centeno Lazcano, a quienes se les ordenó que estuviesen de pie y descaperuzados mientras leían las peticiones o hiciesen relación. Lo mismo ordenó a las personas que asistían a dichas sesiones, dado que el virrey consideró que el decoro representado por estos oficiales no alcanzaba la dignidad regia suficiente.

Ello avivó protestas que concluyeron en la ausencia de dichos ministros para despachar, a los que se les multó por desobediencia, al tiempo que se les prohibió innovar en el estilo. Sin embargo, los escribanos públicos y alcaldes ordinarios tramitaron al Consejo de Indias los daños e inconvenientes que esta reforma implicaría a la autoridad de sus oficios, así como en la representación con respecto a los jueces y escribanos, entre otras, la pérdida de valor y estimación, al igual que un notable perjuicio a la Real Hacienda. No obstante, el monarca concedió por cédula de 2 de octubre de 1676 que se le hiciese gracia perpetuando «este honor en sus personas y

${ }_{119}$ Memorial para Juan José de Austria sobre el estado de la Monarquía (1677), BNE, Ms.18055: 213v.

${ }^{120}$ Foucault 1978: 81.

${ }^{121}$ Cañeque 2004b: 616.

${ }^{122}$ Hanke 1980, V: 72. 
oficios». Este cumplimiento se hizo efectivo tras depositar una retribución de un total de 3000 pesos de contado, a 250 pesos cada uno de los ocho escribanos públicos más los cuatro de la provincia que tenía la ciudad de Los Reyes, para aquellos futuros oficiales que entraban por renunciación o por compra, retribuyendo la media anata más seis ducados por esta regalía. ${ }^{123}$

Esta reforma adquirió un carácter muy peculiar al quebrar una forma de gobierno establecida desde hacía décadas, que provocó un cambio concluyente tras la llegada de Castellar. La Corona vio decisiva la intervención del virrey, y aprovechó esta situación para emplazar la potestad regia sobre los oficios designados desde el Consejo y Cámara de Indias, que la costumbre y las apropiaciones por parte de los oidores llevaban a cabo durante las ausencias de virreyes. Ello propició que el Consejo de Indias consolidase dichos privilegios, con la salvedad de que a partir de este momento fue la Corona la que oficializó esta práctica a través de un pago a la Real hacienda. En definitiva, desde Madrid, mediado por el virrey, se pasó a perpetrar un control efectivo de las prerrogativas y protocolo que hasta el momento se había desplegado de manera particular y sin consulta. Estas desavenencias corregidas por Castellar mostraron un profundo desapego por las audiencias como autoridad y orden virreinal, ya que no se les había delegado potestad por mandato regio.

Asimismo ocurrió con el Tribunal de la Santa Cruzada, organismo contra el que don Baltasar de la Cueva actuó de manera drástica, escindiéndole numerosos privilegios y fueros sobre varios ministros y tesoreros que disfrutaban de negocios particulares. A partir de entonces, el virrey apuntó que solo se valiese actuar "por decreto suyo", sin que nadie se eximiese de la jurisdicción ordinaria. De lo contrario, serían castigados por los delitos que cometiesen, sin poder aferrarse a los fueros particulares y leyes que por bulas pontificias se le habían delegado, siendo esto gran inconveniente a la «buena administración de Justicia». ${ }^{124}$ Desde la Corte madrileña, se ordenó implantar esta nueva política, fomentada desde la publicación en Sevilla en 1672 de la obra Norte de la Contratación, por

${ }^{123}$ AGI, Lima, 77, N.37.

${ }^{124}$ AGI, Lima, 12, s.f. 
José de Veitia y Linaje. En ella, se defendía la independencia y superior jurisdicción de la casa de comercio sevillana, frente a los privilegios y fueros del comisario general de cruzada y otros consejos, con el único fin de fomentar el «beneficio, y bien público, y por la mayor utilidad, y descanso de lo universal del comercio». ${ }^{125}$ Castellar conoció esta obra mientras ejerció como consejero de Indias, la cual mostraba una concentración de fueros en los más altos organismos de la monarquía — en este caso la Casa de la Contratación-, así como una redefinición de los oficios y privilegios concedidos hasta el momento. Este fue el prolegómeno de los graves enfrentamientos que sufrió Castellar respecto a la administración de los asuntos hacendísticos en Indias, entre otras, por extralimitar sus competencias sobre el Consulado de Comerciantes que le ocasionó graves inconvenientes y, finalmente, su destitución como virrey, aprovechado en Madrid para restituir el poder ordinario al alter ego en las Indias. ${ }^{126}$

\section{CONCLUSIONES}

El gobierno interino de la Audiencia de Lima (1672-1674) tuvo como marco común la rearticulación de los virreinatos americanos en su conjunto, circunscritos al proceso de reconfiguración política donde se encontraba inserta la Monarquía Católica de Carlos II. Si bien por una parte fue necesario eliminar los gobiernos interinos regidos por audiencias — como se observa en la legislación tramitada entre 1620 y 1680_, al mismo tiempo, urgía delimitar el poder absoluto que habían acaparado los virreyes — representado en el conde de Castellar - a uno ordinario. Este fue el momento que aprovechó la Audiencia de Lima para acaparar ciertas competencias viceregias. Ahora bien, el gobierno interino presidido por el tribunal de justicia limeńo a la muerte del conde de Lemos evidenció una insuficiencia de autoridad, que conllevó a una inestabilidad e imprecisión política, al igual que a una de falta de inmediatez a la hora de acudir administrativa, gubernativa y militarmente en el reino peruano. Además, entrecruzó competencias civiles y jurídicas cuando

${ }^{125}$ Veitia y Linaje 1671: f. 17r.

${ }^{126}$ AGI, Escribanía, 536B, f. 1147r. 
alcanzó el máximo poder virreinal, manifestando una carencia de mediación y comunicación directa con el Consejo de Indias. Por ello, entre otras, hubo numerosas peticiones al Consejo para que los presidentes de audiencias recayeran en caballeros de capa y espada frente a letrados, con el fin de eliminar ciertas competencias que solventaban congregar el poder en uno solo frente a la multiplicidad de la audiencia. Lo que se pretendió fue una mayor centralización del poder y concentración de competencias en gobernadores y capitanes generales, de ahí la urgencia por acabar con los gobiernos interinos.

Las inconsistencias políticas durante el gobierno de la Audiencia de Lima se manifestaron debido a la falta de unidad que de por sí el tribunal solo mantenía como proyección simbólica del monarca — la unión del presidente y los oidores - pero no natural que sí congregaba el virrey. Las ausencias del alter ego se entendieron como falta de equidad, así como un claro manifiesto de desafecto, frialdad y abandono del monarca a los reinos, como garante de paz y buen gobierno, evitando revueltas y sublevaciones. Por lo tanto, la presencia de un virrey en las Indias que congregase la potestad mayestática fue más que esencial para la reestructuración administrativa de los reinos. Su figura y casa reducían la distancia y materializaba la ubicuidad del soberano, un asunto que no quedó del todo resuelto a finales del siglo XVII con la destitución del conde de Castellar, que puso en tela de juicio todas estas reformas. No obstante, durante los gobiernos del duque de la Palata y del conde de la Monclova se reestablecieron ciertas transformaciones que permitieron apaciguar dicha situación.

A pesar de todo, la Corona decidió mantener a la Audiencia —oidor decano al frente- al mando del gobierno interino por dos motivos. Era el organismo más antiguo, de mayor relevancia y magnificencia junto al virrey, por lo que le hipostasiaba de potestad en la res pública. Por otro lado, porque el virrey residía momentáneamente, frente a las audiencias y oidores que permanecían en el tiempo, los cuales mantenían un conocimiento pleno del reino. Además, los letrados llegaron a instituir verdaderas redes clientelares que le permitieron articular y gestionar el reino peruano a nivel local. Las dificultades procedieron entre los miembros y redes de patronazgo de la Audiencia frente a los servidores del virrey tras su muerte, 
ya que, aunque todos servían al rey, cada uno luchaba por sus intereses. Estos problemas no presentan únicamente un enfrentamiento de poder dicotómico entre el alter ego y el tribunal, ni el virrey Castellar exhibió una defensa centralista regia. Este último se presentó como uno de los «virreyes absolutos» dado su hipóstasis y la talla de su linaje, que le llevó a defender todo aquello que suponía mantenía conforme a derecho, lo que le provocó numerosos altercados y su posterior destitución tras la llegada de una nueva facción a la Corte de Madrid. La recomposición política que realizó la audiencia limeña, así como posteriormente el conde de Castellar, ha permitido analizar la esencia de los últimos virreyes con áurea mayestática regia derivada del gobierno interino al mando del tribunal limeño, las situaciones con las que tuvo que hacer frente la Real Audiencia, así como el papel incondicional de mando ejercido por los virreyes.

\section{BIBLIOGRAFÍA}

Adamson, John. 2000. «The making of the Ancien-Régime Court 1500-1700». En Adamson, John (ed.). The Princely Courts of Europe 1500-1700. London: Seven Dials, 7-41.

Alighieri, Dante. 2009. Monarquía. Madrid: Tecnos.

Aquino, Tomás de. 1959. Suma Teológica. Madrid: Biblioteca de Autores Cristianos. Aristóteles. 2014a. Acerca del alma, Madrid: Gredos.

Aristóteles. 2014b. Metafísica. Madrid: Gredos.

Aristóteles. 2015. Política, Madrid: Alianza Editorial.

Arregui Zamorano, Pilar. 1985. «Poder de los virreyes del Perú: un manuscrito inédito del siglo XVII». Historiografía y bibliografía Americanistas. Volumen 29, número2: 3-97.

Arrieta Alberdi, Jon. 1994. El Consejo Supremo de la Corona de Aragón (1494-1707). Zaragoza: Institución Fernando el Católico.

Bertrand, Michel. 2005. Pouvoirs des familles, familles de pouvoir. Toulouse: Université de Toulouse II-Le Mirail. https://doi.org/10.4000/books.pumi.39496

Bodino, Juan. 1590. Los Seis Libros de la República. Turín: Herederos de Bevilaqua. Boone, Rebecca Ard. 2014. Mercurino di Gattinara and the Creation of the Spanish Empire. Londres y Brookfield: Pickering et Chatto.

Burkholder, Mark A. y Dewitt Samuel Chandler. 1984. De la impotencia a la autoridad: la Corona española y las Audiencias en América, 1687-1808. Ciudad de México: Fondo de Cultura Económica.

Cañeque, Alejandro. 2004a. The King's Living Image. The culture and politics of viceregal power in colonial Mexico. New York: Routledge. 
Cañeque, Alejandro. 2004b. «De sillas y almohadones o de la naturaleza ritual del poder en la Nueva Espańa de los siglos XVI y XVII». Revista de Indias. Volumen LXIV, número 232: 609-634.

Cañeque, Alejandro. 2005. «De parientes, criados y gracias. Cultura del don y poder en el México colonial (siglo XVI-XVII)». Histórica. Volumen XXIX, número1: 7-42.

Cañeque, Alejandro. 2014. «El simulacro del rey». En Aznar, Daniel, Hanotin, Guillaima y Niels F. May (eds.), À la place du roi. Vice-rois, gouverneurs et ambassadeurs dans les monarchies française et espagnole (XVI'-XVIII siècles). Madrid: Casa Velázquez, 181-208.

Cañeque, Alejandro. 2018. Un cuerpo de dos cabezas. La cultura política del poder en la Nueva España siglos XVI y XVII. Puebla: Educación y Cultura.

Caracuel Moyano, Rocío. 1966. «Los mercaderes del Perú y la financiación de los gastos de la Monarquía, 1650-1700». Actas del XXXVI Congreso Internacional de americanistas, IV: 335-343.

Carrió-Invernizzi, Diana. 2008. El gobierno de las imágenes: ceremonial y mecenazgo en la Italia española de segunda mitad del siglo XVII. Madrid/Frankfurt: Iberoamericana/Vervuert. https://doi.org/10.31819/9783954872725

Castillo de Bobadilla, Jerónimo. 1649. Política para corregidores. Madrid: Imprenta Reak.

Cortiada, Sebastián. 1676. Discurso sobre la jurisdición del Excelentíssimo Señor Capitán General del Principado de Cataluña. Barcelona: Josef Forcada.

Elias, Norbert. 2012. La sociedad cortesana. Ciudad de México: Fondo de Cultura Económica.

Elliott, John H. 2011. El Viejo Mundo y el Nuevo (1492-1650). Madrid: Alianza Editorial.

Fernández Sotelo, Rafael Diego. 2007. «Las Reales Audiencias Indianas como base de la organización político-territorial de la América Hispana». En Becerra Jiménez, Celina G. y Rafael Diego-Fernández Sotelo (coords.). Convergencias y divergencias. México y Andalucía: siglos XVI-XIX. Ciudad de México: El Colegio de Michoacán y Universidad de Guadalajara: 21-68.

Freyre, Antonio. 1681. Piratas de la America y luz a la defensa de las costas de Indias Occidentales, Colonia: Lorenzo Struickman.

Foucault, Michel. 1978. La arqueología del saber. Madrid: Siglo XXI.

Fuentes, Manuel Atanasio. 1859. Memorias de los virreyes que han gobernado el Perú, durante el tiempo del coloniaje español. Lima: Librería Central de Felipe Bailly, 1859, 6 vols.

Grossi, Paolo. 2003. Mitología jurídica de la modernidad. Madrid: Trotta.

Gundissalinus, Dominicus. 2015. De unitate et uno. Pamplona: Ediciones Universidad de Navarra.

Han, Byung-Chul. 2016. Sobre el poder. Barcelona: Herder. 
Hanke, Lewis. 1980. Los virreyes españoles en América durante el gobierno de la Casa de Austria. Perú. Madrid: Atlas, 6 vols.

Henshall, Nicholas. 2010. The zenith of european monarchy and its elites. The politics of culture, 1650-1750. Londres: Palgrave Macmillan. https://doi. org/10.1007/978-1-137-08875-8

Hespanha, António M. 1993. La gracia del derecho. Economía de la cultura en la Edad Moderna. Madrid: Centro de Estudios Constitucionales.

Jiménez Castillo, Juan. 2016. «La percepción de un tercer virreinato americano en el siglo XVII (1650-1717)». Librosdelacorte.es. Volumen 12, número 8: 25-62.

Jiménez Castillo, Juan. 2019. La Reconfiguración de los reinos de Indias. La transfiguración del poder politico de los virreyes. Tesis de doctorado en Historia. Madrid: Universidad Autónoma de Madrid.

Kantorowicz, Ernst H. 2012. Los dos cuerpos del rey. Un estudio de teología política medieval. Madrid: Akal.

Konetzke, Richard. 1953-1962. Colección de Documentos para la Historia de la Formación Social de Hispanoamérica (1493-1810). Madrid: Consejo Superior de Investigaciones Científicas, 5 vols.

Lalinde Abadía, Jesús de. 1967. «El régimen virreino-senatorial en Indias». Anuario de Historia del Derecho Español. Volumen XXXVII: 5-244.

Leyes de Indias. 1681. Recopilación de leyes de los reynos de las Indias. Madrid: Julián de Paredes, 4 vols.

Leyes de Indias. 1774. Recopilación de leyes de los reynos de las Indias con el indice general. Madrid: Bartholomé Ulloa, 4 vols.

Lockhart, James. 1986. Los de Cajamarca. Un estudio social y biográfico de los primeros conquistadores del Perú. Lima: Milla Batres. 2 vols.

Lohmann Villena, Guillermo. 1946. El Conde de Lemos: virrey del Perú. Madrid: Escuela de Estudios Hispano-Americanos.

Lohmann Villena, Guillermo. 1974. Los ministros de la Audiencia de Lima en el reinado de los Borbones (1700-1821). Esquema de un estudio sobre un núcleo dirigente. Sevilla: Escuela de Estudios Hispano-Americanos.

Maquiavelo, Nicolás. 2018. Discursos sobre la primera década de Tito Livio. Madrid: Alianza Editorial.

Martiré, Eduardo. 2005. Las Audiencias y la Administración de Justicia en las Indias. Madrid: Universidad Autónoma de Madrid.

Matienzo, Juan de. 1910. Gobierno del Perú. Buenos Aires: Compañía Sud-Americana de Billete de Banco.

Mendiburu, Manuel de. 1874-1890. Diccionario histórico-biográfico del Perú. Lima: Imprenta J. Francisco Solís, 8 vols.

Merluzzi, Manfredi. 2006. «Mediación política, redes clientelares y pacificación del reino del Perú del siglo XVI. Observaciones a partir de los papeles «Pizarro - La Gasca». Revista de Indias. Volumen LXVI, número 236: 87-106. 
Merluzzi, Manfredi. 2016. «La Audiencia de Lima entre la administración de justicia y las luchas políticas por el control del virreinato (siglo XVI)». En Caselli, Elisa (coord.). Justicias, agentes y jurisdicciones: de la Monarquía Hispánica a los Estados Naciones (España y América, siglos XVI-XIX). Madrid: Fondo de Cultura Económica, 315-344.

Mitchell, Silvia Z. 2019. Queen, Mother, and Stateswoman. Mariana of Austria and the Government of Spain. Pennsylvania: The Pennsylvania State University Press. https://doi.org/10.5325/j.ctv14gnzwc

Mugaburu, José y Francisco de Mugaburu. 1918. Diario de Lima (1640-1694). Lima: Imprenta y Librería Sanmarti, 2 vols.

Muro Romero, Fernando. 1975. Las Presidencias-Gobernaciones en Indias. Sevilla: Escuela de Estudios Hispano-Americanos.

Oliveira, António de. 1991. Poder e oposiçao política em Portugal no periodo filipino (1580-1640). Lisboa: Difel.

Osorio, Alejandra B. 2008. Inventing Lima. Baroque Modernity in Peru's South Sea Metropolis. New York: Palgrave Macmillan. https://doi. org/10.1057/9780230612488

Pérez Vejo, Tomás. 2018. Repúblicas urbanas en una Monarquia Imperial. Imágenes de ciudades y orden politico en la América virreinal. Bogotá: Crítica.

Plotino. 1985. Enéadas. Madrid: Gredos.

Puente Brunke, José de la. 2012. «Las estrellas solo lucen cuando el sol se pone. Los ministros de la audiencia de Lima en el siglo XVII y sus expectativas». Illes $i$ imperis: Estudios de historia de las sociedades en el mundo colonial y post-colonial. Número 14: 49-68.

Puente Brunke, José de la. 2016. «Codicia y bien público: Los ministros de la Audiencia en la Lima seiscentista». Revista de Indias. Volumen 66, número 236: 133-148.

Puente Brunke, José de la. 2019. «El virreinato peruano en el primer siglo XVIII americano (1680-1750). Organización territorial y control administrativo». En Lavallé, Bernard (ed.), Los virreinatos de Nueva España y del Perú. Un balance historiográfico. Madrid: Casa Velázquez, 83-97.

Real Academia Española. 1726-1739. Diccionario de autoridades. Edición digital. https://webfrl.rae.es/DA.html

Rivero Rodríguez, Manuel. 2019. «La cour du roi et les cours des vice-rois: la crise du gouvernement de la monarchie espagnole au XVII ${ }^{e}$ siècle». Histoire, Economie et Société. Número 3: 33-49. https://doi.org/10.3917/hes.193.0033

Rodríguez Vicente, María Encarnación. 1960. El Tribunal del Consulado de Lima en la primera mitad del siglo XVII. Madrid: Consejo Superior de Investigaciones Científicas.

Saavedra Fajardo, Diego. 1999. Empresas politicas. Madrid: Cátedra.

Salinero, Gregorio. 2017. Hombres de mala corte. Desobediencias, procesos politicos y gobierno de Indias en la segunda mitad del siglo XVI. Madrid: Cátedra. 
Schäfer, Ernesto. 2003. El Consejo Real y Supremo de las Indias. Su historia, organización y labor administrativa hasta la terminación de la Casa de Austria. Madrid: Marcial Pons, 2 vols.

Semboloni, Lara. 2014. La construcción de la autoridad virreinal en Nueva España, 1535-1595. Ciudad de México: El Colegio de México.

Solórzano Pereira, Juan de. 1648. Política Indiana. Madrid: Diego Díaz de la Carrera. Suárez Espinosa, Margarita. 2001. Desafíos transatlánticos: Mercaderes, banqueros y el estado en el Perú virreinal, 1600-1700. Lima: Instituto Francés de Estudios Andinos, Fondo de Cultura Económica e Instituto Riva-Agüero.https://doi. org/10.4000/books.ifea.4039

Suárez Espinosa, Margarita. 2015. «Imperio, virreyes y arzobispos en el Perú del siglo XVII: historia de un conflicto». En Mayer, Alicia y José de la Puente Brunke (eds.). Iglesia y sociedad en la Nueva España y el Perú. Pamplona: Analecta: 215-228.

Suárez Espinosa, Margarita. 2017a. «Beneméritos, criados y allegados durante el gobierno del virrey conde de Castellar: ¿el fin de la administración de los parientes?». En Suárez Espinosa, Margarita (ed.), Parientes, criados y allegados: Los vinculos personales en el mundo virreinal peruano. Lima: Instituto Riva-Agüero: 69-96.

Suárez Espinosa, Margarita. 2017b. «Presión fiscal y crisis política: la destitución del virrey conde de Castellar, 1674-1678». En Martínez Millán, José; Labrador Arroyo, Félix y Filipa Maria Valido-Viegas de Paula-Soares (coords.). ¿Decadencia o reconfiguración?: las monarquías de España y Portugal en el cambio de siglo (1640-1724). Madrid: Polifemo: 339-350.

Tau Anzoátegui, Víctor. 2016. El Jurista en el Nuevo Mundo. Pensamiento. Doctrina. Mentalidad. Berlín: Max Planck Institute. https://doi.org/10.12946/gplh7

Torres Arancivia, Eduardo. 2014. Corte de virreyes. El entorno del poder en el Perú del siglo XVII. Lima: Instituto Riva-Agüero.

Tovar Velarde, Jorge. 1957-1958. «La Audiencia de Lima, 1705-1707. Dos años de Gobierno criollo en el Perú». Revista Histórica. Volumen 23: 338-453.

Vargas Ugarte, Rubén. 1971. Historia General del Perú. Lima: Carlos Milla Batres, 10 vols.

Veitia y Linaje, José. 1671. Norte de la Contratación de las Indias Occidentales. Sevilla. Vilosa, Rafael de. 1670. Dissertación jurídica y política sobre si el que mata al lugarteniente general de Su Magestad de alguno de los reynos de la corona de Aragón (a quien comúnmente llamamos virey) cometa crimen de lesa magestad. Madrid: Lucas Antonio de Bedmar.

Fecha de recepción: 19/V/2020 Fecha de aceptación: 24/VII/2020 